\title{
Fungus-beetle food web patterns in boreal forests
}

\section{Особенности трофических сетей жкесткокрылых-мицетофагов

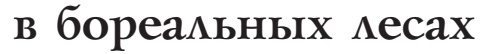

\author{
Dmitry S. Schigel \\ Амитрий С. Щигель
}

Metapopulation Research Group, Department of Biosciences, Faculty of Biological and Environmental Sciences, PO Box 65 (Viikinkaari 1) FI00014 University of Helsinki, Finland. E-mail: dmitry.shchigel@helsinki.fi

KEY WORDS: Fungivory, Coleoptera, Basidiomycetes, trophic interactions, taiga, Finland.

КЛЮЧЕВЫЕ СЛОВА: Мицетофагия, жесткокрылые, базидиомицеты, пищевые связи, тайга, Финляндия.

ABSTRACT. Fungivorous Coleoptera were studied in seven protected boreal forests in northern, eastern and southern Finland. Trophic interactions of wood-decaying Basidiomycetes and community structure among Coleoptera were approached with a food web analysis. 87 links of the 37 commonest polypore species (24 of them beetle-colonized) and 32 associated beetle species were summarized in a unified diagram. Thirteen $(35 \%)$ of the 37 commonest polypore species hosted no beetle larvae. The fungus-beetle community is described through hostconsumer relations as seen from frequencies of fungal fruit bodies in forest compartments and from frequencies of occurrence of beetle larvae in these fungi. Lignicolous fungi with perennial fruit bodies support more beetle species than those with annual fruit bodies.

РЕЗЮМЕ. Жесткокрылые-мицетофаги были изучены в семи охраняемых бореальных лесах в Северной, Восточной и Южной Финляндии. Пищевые связи и структура сообщества древоразрушающих базидиомицетов и связанных с ними жесткокрылых представлены в виде анализа трофической сети. 87 связей между 37 наиболее распространенными видами трутовых грибов (24 из них были заселены жесткокрылыми) и 32 видами жесткокрылых сведены в единую диаграмму. Тринадцать видов (35\%) среди 37 наиболее распространеных грибов не были заселены личинками жесткокрылых. Сообщество грибов и жесткокрылых описано в свете взаимоотношений «хозяин-потребитель» на основании частоты встречаемости грибов в лесных биотопах и частоты встречаемости жесткокрылых в этих грибах. Многолетние плодовые тела древоразрушающих грибов поддерживают более высокое видовое разнообразие жесткокрылых-мицетофагов по сравнению с однолетними.

\section{Introduction}

Wood-decaying fungi play a key role in the nutrient cycling of forest ecosystems, and their fruit bodies are consumed by a variety of beetles from several families.
At least 2000 species of fungi comprise an important component of the nearly 7000 saproxylic (dead-wood dependent) species in North Europe [Stokland et al. 2006]. Fungal kingdom provides those ecologically irreplaceable mediator species that modify organic macromolecules of wood into compounds digestible by animal consumers. Polypores, i.e. poroid non-bolete Basidiomycetes, do not form a monophyletic group [Hibbett et al. 2007]. Ecologically, too, polypores share niches with wood-rotting agarics and corticioid fungi, and neighbour myxomycetes and other organisms of the dead wood; a few polypore species fruit on the ground. In an ancient and coherent ecological triangle of a tree, fungus and beetle [Crowson 1981], beetle fungivory is a fundamental aspect of terrestrial ecology. All stages of the polypore life cycle, from spore to wood-penetrating mycelium to fruit-body growth, sporulation and decomposition, are targets of certain fungus-feeding beetles. Some of these beetles visit fungi only as adults, while others undergo their larval development, or their entire life cycle takes place within living or dead fruit body of fungus. In general, polypore fruit bodies may be considered shortterm habitats for beetles, often existing for only a few weeks, even though perennial fruit bodies of some species may stay on trees for decades [Niemelä 2005].

Coleoptera emerging from pupae seek for the mating partner, and disperse to colonize new habitats, or new generations may recycle in the parental fruit body. The majority of beetles colonize fungal fruit bodies after their sporulation and death, and perennial mycelia are typically producing new fruit bodies for several years. Fungal fruit body, and perennial one in particular, is a structured substratum with different parts occupied by beetle larvae of different species, often spatially isolated. Species turnover takes place on a seasonal basis, but also as a succession during the whole span of fruit body persistence. Some beetle species, in particular those occupying living fruit bodies, utilise only a few structurally similar fungi, while others, e.g. inhabitants of decomposed fungi, use several taxonomically unrelated hosts. Even though the contrast between living and 
dead fruit bodies may be decisive for beetle host preferences, it is usually difficult to judge the moment of fruit body death: transitional conditions between the extremes of young and decomposed fruit body are common and are especially favoured by fungivorous beetles. Even though the descriptive terminology varies from study to study, beetles with larvae feeding on fungal fruit bodies are generally called fungivorous. Fungivorous beetles co-inhabit fungal fruit bodies together with Diptera, Lepidoptera, Hymenoptera, and other invertebrates. Coleoptera feeding on uncommon fungi are slow to collect and rear in computable quantities and their study is hampered by difficulties in identifying the rarest fungal species. The compact and species-rich fungus-beetle communities are in the focus of a number of studies in ecology and population biology, usually in a conservation context [Økland 1995, Andersen et al. 2000, Thunes et al. 2000, Ehnström \& Axelsson 2002, Jonsell \& Nordlander 2004, Komonen 2008], for the detailed literature review see Schigel [2009]. The popularity of the fungus-beetle study system and increasing accumulation of species association data calls for the food web overview and the description of the main host-consumer interaction types.

Food web analysis grew increasingly popular in recent decades; for overviews of early ideas see Schoener [1989] and Havens [1993]. A quantitative food web approach has been successfully applied to ecological studies dealing with host-parasitoid [Memmott et al., 1994; Müller et al., 1999; Lewis et al., 2002; Morris et al., 2004; Albrecht et al., 2007; Barbosa et al., 2007; Tylianakis et al., 2007; van Veen et al., 2008] and plantpollinator systems [Memmott, 1999; Memmott \& Waser, 2002]. Environmental factors structuring communities of fungivorous insects have been studied less extensively: communities of fungivorous flies are governed by the size of mushroom pileus and desiccation tolerance [Worthen et al., 1996], and larger fungal habitats may buffer the environmental load resulting in a nested-subset pattern of associated insect community [Worthen et al. 1998]. The coexistence of consumer species in a host is one of the main characteristics of nearly any food web, and it is a precondition for competitive interactions.

In this study I intended to apply a food web approach to the beetle-fungus interaction data. Based on the data collected in Finnish boreal forests, I aimed to describe and to visually outline the food web comprised by the key species of fungivorous beetles reared from the fruit bodies (mycelia were not considered) of the commonest boreal polypores, to identify interaction patterns within these communities, and to explore the contributions of the fungal species to the larval diet of Coleoptera.

\section{Materials and methods}

Polypores were surveyed in spruce- and pine-dominated old-growth forests in the Ylläs-Aakenus and Pisavaara fells in western Finnish Lapland [Schigel et al., 2006], the North Karelian Biosphere Reserve [Schigel et al., 2004], the Kirjovaara and Kolvananuuro reserves in eastern Finland, and the Kolovesi [Schigel, 2007] and Repovesi National Parks in September-October 2001-2006, and associated Coleoptera were collected [Schigel, 2009]. Each polypore species discovered in a forest was registered if present in the forest compartment (metsäkuvio), and the percentage of the forest compartments with such species was used as a measure of the host abundance for the entire study area. The dataset treated here comprises a selection of the

Table 1. The commonest polypores in Finnish boreal forests as seen from proportion of the occupied forest compartments. Таблица 1. Наиболее распространенные (по доле заселенных биотопов) трутовые грибы в бореальных лесах Финляндии.

\begin{tabular}{|c|c|c|c|}
\hline Species & $\mathbf{C}$ & Species & $\mathbf{C}$ \\
\hline Fomes fomentarius (L.: Fr.) & 0.738 & Oligoporus sericeomollis (Romell) M. Bondartseva & 0.314 \\
\hline Trichaptum abietinum (Pers.: Fr.) Ryvarden & 0.670 & Phellinus ferrugineofuscus (P. Karst.) Bourdot \& Galzin & 0.299 \\
\hline Fomitopsis pinicola (Sw.: Fr.) P. Karst. & 0.660 & Trichaptum fuscoviolaceum (Ehrenb.: Fr.) Ryvarden & 0.269 \\
\hline Phellinus igniarius (L.: Fr.) Quél. & 0.638 & Phellinus laevigatus (P. Karst.) Bourdot \& Galzin & 0.252 \\
\hline Inonotus obliquus (Pers.: Fr.) Pilát & 0.606 & Antrodia albobrunnea (Romell) Ryvarden & 0.203 \\
\hline Phellinus viticola (Schwein. ex Fr.) Donk & 0.573 & Phellinus conchatus (Pers.: Fr.) Quél. & 0.200 \\
\hline Antrodia serialis (Fr.) Donk & 0.502 & Onnia leporina (Fr.) H. Jahn & 0.189 \\
\hline Gloeophyllum sepiarium (Wulfen: Fr.) P. Karst. & 0.495 & Phellinus lundellii Niemelä & 0.181 \\
\hline Piptoporus betulinus (Bull.: Fr.) P. Karst. & 0.484 & Postia caesia (Schrad.: Fr.) P. Karst. & 0.175 \\
\hline Fomitopsis rosea (Alb. \& Schwein.: Fr.) P. Karst. & 0.443 & Gloeoporus dichrous (Fr.: Fr.) Bres. & 0.159 \\
\hline Antrodia xantha (Fr.: Fr.) Ryvarden & 0.442 & Skeletocutis odora (Sacc.) Ginns & 0.136 \\
\hline Trametes ochracea (Pers.) Gilb. \& Ryvarden & 0.420 & Coltricia perennis (L.: Fr.) Murrill & 0.135 \\
\hline Phellinus chrysoloma (Fr.) Donk & 0.420 & Phellinus pini (Brot.: Fr.) A. Ames & 0.134 \\
\hline Phellinus nigrolimitatus (Romell) Bourdot \& Galzin & 0.373 & Cinereomyces lenis (P. Karst.) Spirin & 0.120 \\
\hline Cerrena unicolor (Bull.: Fr.) Murrill & 0.365 & Meruliopsis taxicola (Pers.: Fr.) Bondartsev & 0.119 \\
\hline Amylocystis lapponica (Romell) Singer & 0.363 & Trametes pubescens (Schumach.: Fr.) Pilát & 0.108 \\
\hline Antrodia sinuosa (Fr.) P. Karst. & 0.354 & Junghuhnia luteoalba (P. Karst.) Ryvarden & 0.107 \\
\hline Phellinus tremulae (Bondartsev) & & Rigidoporus corticola (Fr.) Pouzar & 0.107 \\
\hline Bondartsev \& P.N. Borisov & 0.343 & Climacocystis borealis (Fr.) Kotl. \& Pouzar & 0.107 \\
\hline
\end{tabular}


commonest polypore species which were registered in more than $10 \%$ of forest compartments. The $10 \%$ frequency limit was set to frame the commonest hosts and their consumers from the entire fungus-beetle food web. Intact parts of the polypore fruit bodies were collected for identification and herbarium documentation, and dried in mushroom dryers with ventilated air at $+40-45^{\circ} \mathrm{C}$. In difficult cases provisional names were later approved by microscopic study of sections mounted in Cotton Blue or Melzer's reagent at $\times 1250$ magnification and phase contrast illumination. Fungal collections are preserved in the Herbarium of the Botanical Museum, Finnish Museum of Natural History, University of Helsinki $(\mathrm{H})$; their nomenclature (Table 1) follows Niemelä [2005].

Fruit bodies which contained beetle larvae were placed for rearing in plastic 0.5 -litre containers in the lab. Number of fungal specimens in rearing varied between 30 and 40 per species. Samples were treated individually Fruit bodies of Fomes fomentarius dominated by Bolitophagus reticulatus and Cis jacquemartii, Fomitopsis pinicola dominated by Cis glabratus, and Fomitopsis rosea dominated by Cis dentatus were excluded from the rearing routine. Each container was quarter-filled with gardening peat to serve for pupation medium. Perforated lids allowed slow drying of the fruit bodies. Rearing chambers were not moistened during the rearing. Containers were kept for 2-3 months in outdoor temperature in Helsinki, then exposed to room temperature for further two months, and after that checked for insects. Beetle larvae or reared adults were registered as incidences of trophic linkages in accor- dance with Lawrence [1973] criteria of fungivory. Numbers of such fungus-beetles trophic links were used to calculate the dietary spectra of individual beetles species; beetle abundances were not measured. After completing the mounting, beetles will be donated to the Finnish Museum of Natural History, University of Helsinki. Beetle names (Table 2) accord Silfverberg [2004] and Müller et al. [2001].

The fungus-beetle interaction matrix was used to generate the food web based on frequencies with which each fungus species is attacked by each beetle. Fungi that hosted no beetle larvae were also included in the food web. Presence-only frequency measures, i.e. contributions of individual beetle species into the whole account of interactions with a fungus, were used to rank the consumers. Abundances of the hosts were measured through the relative frequency of the fungi, whether or not they had associated beetles; host frequencies across the forest compartments were measured independently from the occurrence frequencies of fungivorous beetles. Properties of the fungus-beetle system were numerically characterized by the host/consumer ratio $(H / P)$, and connectance $(L / H P)$, where $H$ stands for number of species of host fungi, $P=$ number of species of fungivorous beetles, and $L=$ number of links. In the alternative formula for connectance, $2 L / S(S-1), L$ and $S$ are total numbers of links and species. Linkage density, $L D=L /$ $S$, was used to measure the community stability. Direct connectance $\left(C=L / S^{2}\right)$ was used to measure the number of realized links compared with the number of possible links, and generality/vulnerability $G=L /(H+P)$ to measure the mean number of prey per consumer.

Table 2. Coleoptera associated with the commonest polypore fungi in Finland. In the systematic list of families genera and species are listed in alphabetical order. Таблица 2. Жесткокрылые связанные с наиболее распространенными трутовыми грибами Финляндии. В систематическом списке семейств роды и виды приведены в алфавитном порядке.

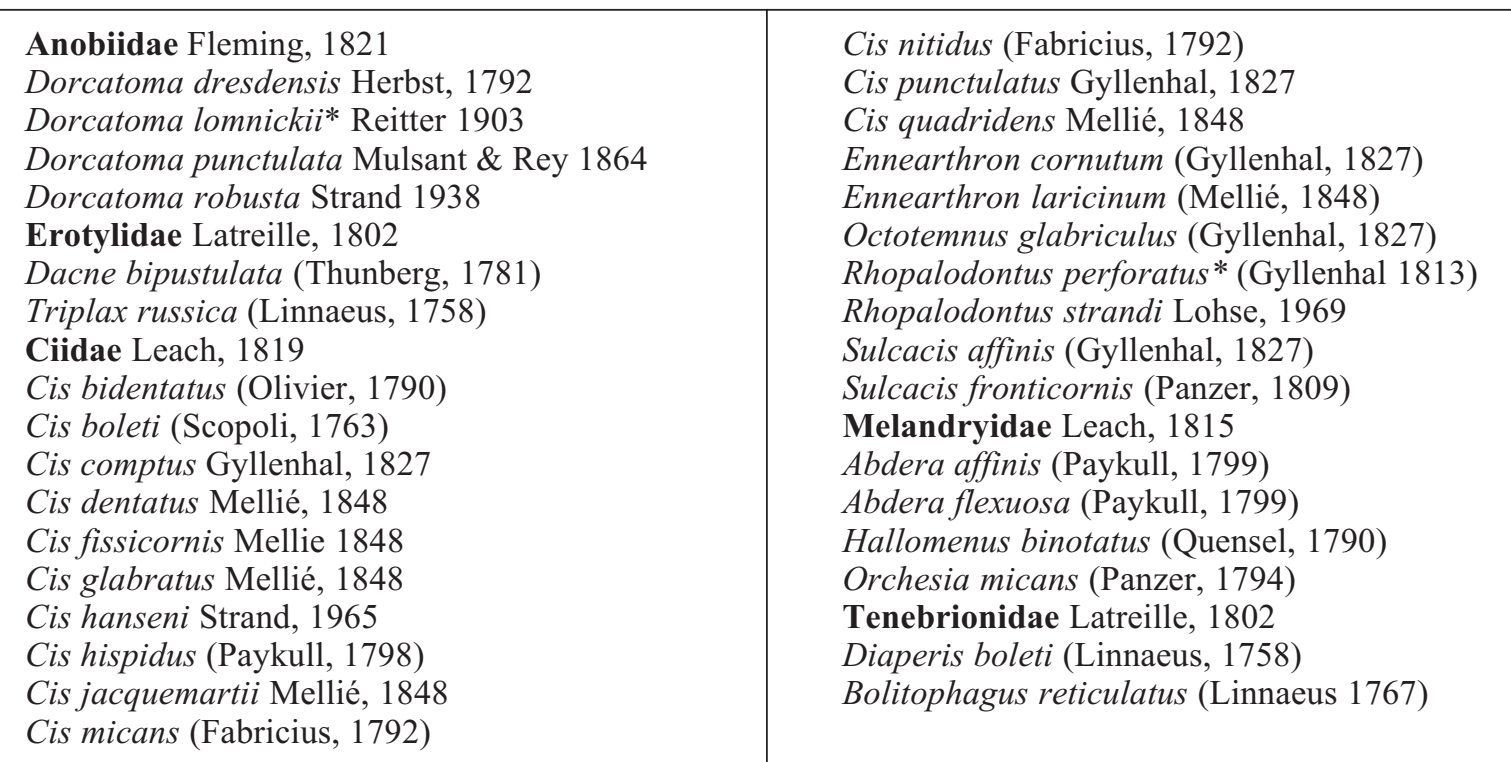

* Identifications of Rhopalodontus perforatus and Dorcatoma lomnickii, both species unreported from Finland [Silfverberg 2004], need further approval. 


\section{Results}

Thirty-two species of fungivorous beetles from five beetle families (Ciidae, Anobiidae, Tenebrionidae, Erotylidae, and Melandryidae, Table 2) were recorded in the fruit bodies of 24 out of 37 species of polypore fungi (Table 1) in 477 forest compartments of seven protected boreal forests in northern, eastern and southern Finland. 87 links were summarized in a unified diagram (Fig 1). Thirteen (35\%) of the 37 commonest polypores hosted no beetle larvae.

The qualitative host-to-consumer, i.e. fungus-to-beetle $H / P$ ratio in the food web of 1.12 indicates an average of 6 consumers per nearly 5 hosts. However, if only 24 inhabited fungi are considered, the actual ratio is lower, 0.72 , i.e. close to three consumers per four hosts. The food web is characterized by connectance 0.11 ( 0.05 with alternative formula), the direct connectance 0.03 , the 1.51-high linkage density, and the generality of 1.53

\section{Discussion}

In order to build a quantitative food web one should know how abundant each species is in the system. For the fungi this measure came from the frequency in forest compartments. For the beetles, instead of the sampled frequency, I used the contribution of individual beetle species into the whole account of beetles interacting with a fungus. As a result, the quantitative food web of fungus-beetle community was constructed based on the abundances of fungi and beetles, and the incidences of trophic relations between them. The traditional food web analysis assumes that interaction frequencies are measured from a same single sampling, but in this study a food web is a visualization of slowly-accumulated rearing data from all over Finland. Unlike the traditional food web analysis which uses the abundance of all interacting species and numbers of interactions per unit area or volume [Lewis et al. 2002], I used presence-only frequency measures, i.e. contributions of individual beetle species into the whole account of interactions with a fungus, which allowed utilizing the data from irregular sampling over a seven-year period. Such methodology, even though lacking a higher precision [Polis 1991] and comparability with related studies, may be used in an analysis of slowly-growing datasets, such as substrate association databases focusing on rare, threat- ened, and poorly-known species. One source of high quality large-scale information suitable for similar investigations are the national frequency scores of species, e.g. Coleoptera [Rassi 1993] and databases used to create Red Lists [Rassi et al. 2010].

The fungus-beetle community was described through host-consumer relations as seen from the frequencies of fungal fruit bodies in forest compartments, and from the frequencies of occurrence of beetle larvae in these fungi. Fungus $v s$. beetle matrix of species interactions in this dataset of 37 fungi and 32 beetles with fungivorous larvae revealed a network of 87 hosts-consumer links. The data illustrates the complexity of fungivorous communities with high generality of consumer species. These consumers, i.e. fungivorous beetles, demonstrate at least three strategies of exploitation of host polypores. I expect both the number of fungivorous species developing in polypores and the level of beetle generality to increase if more species of host fungi are included in the analysis. Moreover, the number of links is likely to increase with larger sets of interacting fungi and beetles, according to the findings of Martinez [1992]. The sampling in this study was exhaustive in the sense that contributions of all registered beetle species to the fungus colonization event were counted. Boreal vegetation and shared polypore and beetle diversity united my data from several collecting sites, and thus I expect the plotted network to reflect genuine co-occurring.

Each of the 24 species of polypores supported larvae of one to twelve species of fungivorous beetles, and 13 remaining species of the commonest fungi hosted no beetle larvae. The most speciose communities of fungivorous beetles were registered in fungi with clustered hibernating or larger perennial fruit bodies: Trametes ochracea (12 species of beetles), T. pubescens (12), Fomes fomentarius (10), Fomitopsis pinicola (7), and Piptoporus betulinus (6). The number of beetle species co-inhabiting a single sample was typically lower, most commonly two-three species. Of the 32 beetle species that attack 24 species of polypores, only five were able to breed in several, often unrelated, species of fungi.

Three types of fungus-beetle relations could be identified in the interaction continuum. Few generalist species utilize a wide range of host fungi, some beetle species are narrowly dependent on one (or two closely related) host fungus, while other beetles are members of speciose communities inhabiting a certain host fungus only. Generalist beetles demonstrate ecological flexibility with larvae developing in a variety of unre-

Fig. 1. Fungus-beetle food web in Finnish boreal forests. Bars on the left represent frequencies of fruit body occurrence of the host polypores from the commonest (top) to least frequent. Only species with more than $10 \%$ fruit body frequency scores in forest compartments were included. Names of fungi which hosted no beetle larvae are set in bold face. Bars on the right represent the gradient of sums of beetle larvae frequencies in the selected fungi, from the most frequent in all fungi (top) to the least frequent. Thickness of the interaction cline reflects the relative contribution of the fungal species to diet of the beetle larvae.

Рис. 1. Пищевая сеть грибы-жесткокрылые в борельных лесах Финляндии. Прямоугольники в левом столбце отображают частоту встречаемости плодовых тел трутовых грибов от наиболее (вверху) до наименее часто встречающихся. Включены только виды грибов встречающиеся как минимум в 10\% обследованных биотопов. Виды грибов, в которых не были обнаружены личинки жесткокрылых отмечены полужирным шрифтом. Прямоугольники в правом столбце показывают градиент сумм частот встречаемости видов жесткокрылых в грибах, от наиболее (вверху) до наименее часто встречающихся. Толщина при основании треугольника, соединяющего вид жесткокрылого с видом гриба показывает относительный вклад вида гриба в пищевой (личиночный) спектр вида жесткокрылого. 


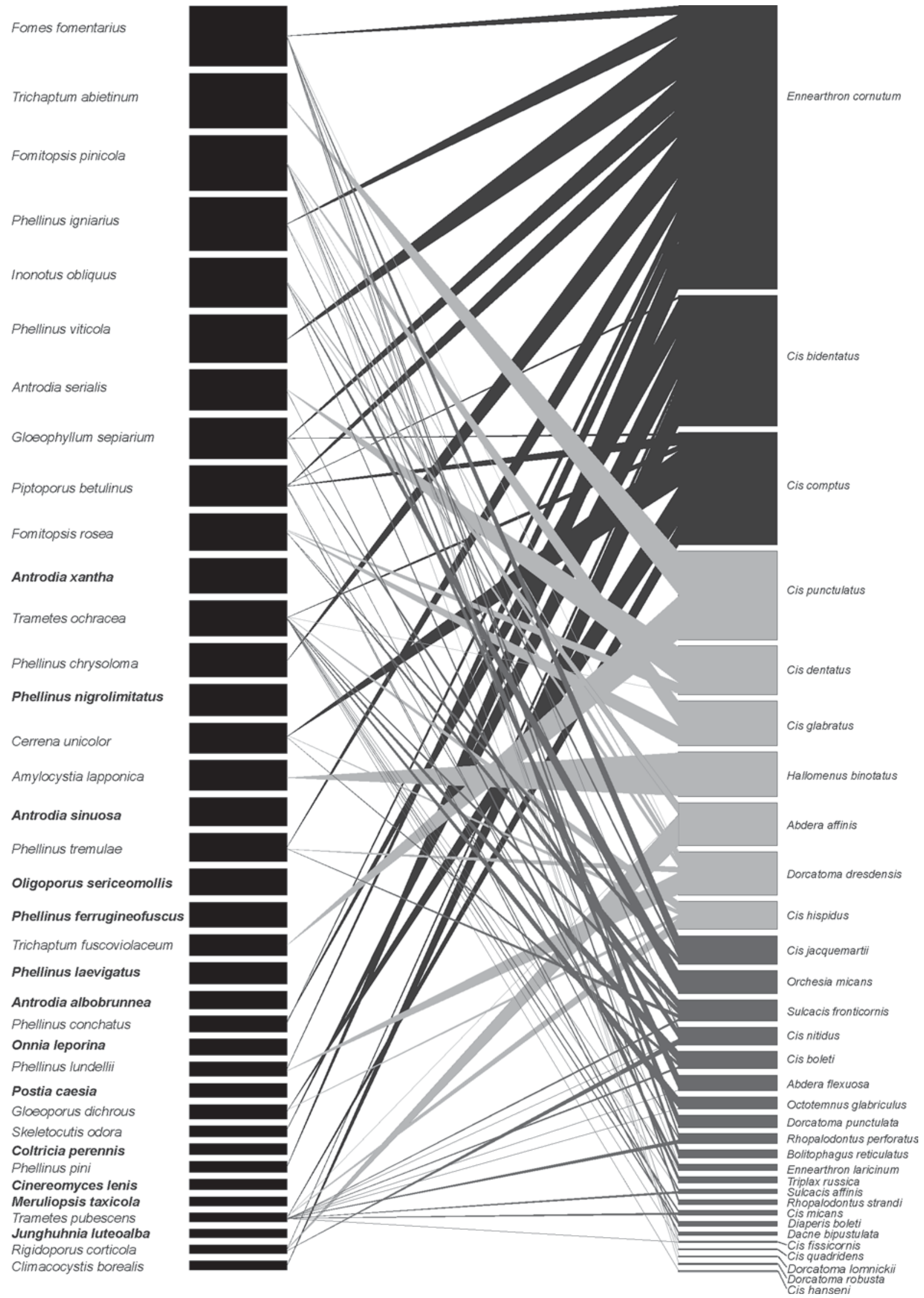




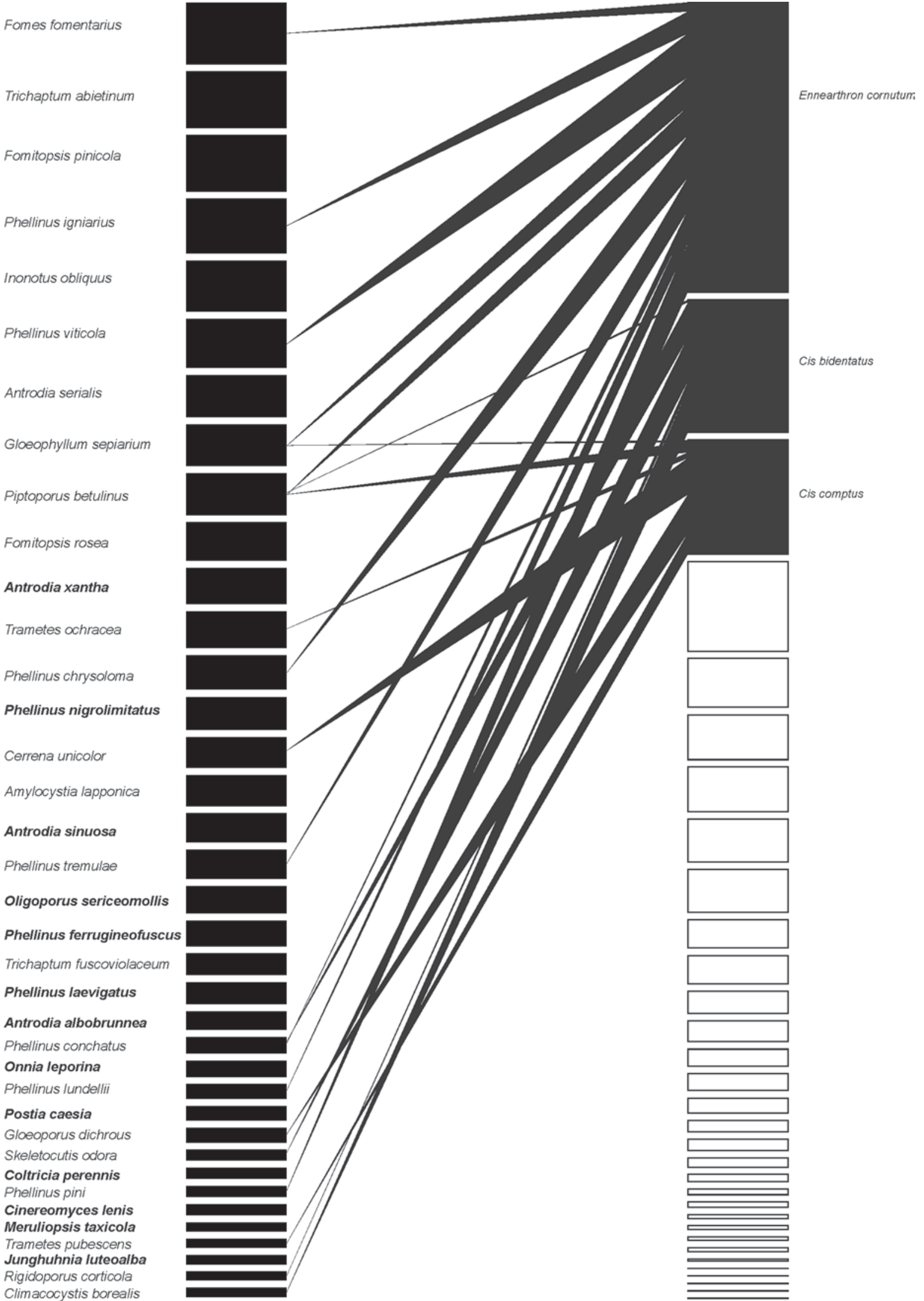

Fig. 2. Fungus-beetle food web in boreal forests: generalists. See Fig. 1 for legend.

Рис. 2. Пищевая сеть грибы-жесткокрылые в борельных лесах Финляндии: генералисты. Условные обозначения — см. Рис. 1. 
lated and structurally diverse host fungi. Such flexibility is, however, not infinite: a broad preference may be identified within the diverse host species range (Fig. $2)$. Ennearthron cornutum, reared from 10 species of polypores, was followed by Cis comptus (6), Dorcatoma dresdensis (6), Cis bidentatus (5), and C. nitidus (5). Larvae of Ennearthron cornutum, Cis bidentatus and C. comptus utilized 5-10 species of host fungi of different frequencies from the commonest Fomes to the least frequent (in the 10\% frequency-limited sampling) Climacocystis. Ennearthron cornutum, a generalist with perennial/Phellinus preference profile, was the most frequently reared species in my material. There were at least ten $(27 \%$ of sampled) polypore species suitable for its larvae in Finland. As seen from Fig. 2, its truly diverse range of host fungi includes hard perennial and fibrous annuals, with both the commonest and less common polypores occupying deciduous (6 polypore species) and coniferous (4) trees. Larvae of Cis bidentatus dwelled in either soft piptoporoid or very soft tyromycetoid fungi; Cis comptus appeared as a trameticolous species. Even though Ennearthron cornutum was the most indifferent in its diet and also the most frequent in sampling, it is noteworthy that generality and frequency do not follow the same decreasing gradient across the whole food web. Some species are efficient in using fewer host fungi, such as Cis punctulatus in Trichaptum spp. and anyhow substantially more frequent than many generalists.

The remarkable position of specialist beetles (oneto-one type of host-consumer interactions) in the middle part of the food web diagram, i.e. next frequent after the generalists, can be interpreted in terms of frequencies of occurrence with the generalist strategy of host use being more efficient, than trophic specialization (Fig. 3). Cis punctulatus is confined to Trichaptum species, pioneer decomposers of dead coniferous trees: Trichaptum abietinum, second commonest in boreal forests, and the less common T. fuscoviolaceum. Such narrow specialization of Cis punctulatus was possible to become established due to the constant supply of Trichaptum fruit bodies in both old-growth and heavily managed forests. Trichaptum fruit bodies are among the first to appear on fresh logs of coniferous trees; most of the biomass of these fungi is concentrated in the sapwood, and Trichaptum-associated beetles utilize not only the thin fruit bodies, but also their merging bases and neighbouring thick mycelial mat under the bark. The contribution of both these fungal hosts to the diet of Cis punctulatus appears in the food web as nearly equal, but if host abundances would be considered not only across, but also within the compartments, I expect the balance be shifted towards Trichaptum abietinum. Hallomenus binotatus larvae utilized a range of soft, watery and ephemeral fruit bodies of tyromycetoid polypores (such as Pycnoporellus fulgens (Fr.) Donk, Postia and Oligoporus spp.) of which only an old-growth-forest indicator Amylocystis lapponica was common enough to appear in the present food web (Fig. 3).
The heterogeneous set of beetle species least frequently reared from the commonest polypores is found in the right-bottom corner of the food web diagram and is recognised by the up-pointed interaction clines (Fig. 1). Many of the host fungi supporting beetles in manyto-one interactions have perennial or semi-perennial (hibernating) fruit bodies. Extended durability of the fruit bodies improves chances to discover the fungus individual both for a beetle looking for habitat and for a researcher surveying the forest for polypores. These beetles form multispecific communities, which tolerate competition with each other in the structured environment of relatively voluminous fruit bodies of perennial and hibernating fungi.

Twenty (63\%) beetle species in the food web were Ciidae, a family closely associated and probably coevolving with polypores. The Ciidae comprise the top six frequent consumer species and fourteen more with various trophic and frequency characteristics. Larvae of Dorcatoma spp. (Dorcatominae; other Anobiidae species mostly boring into wood) are even more confined to robust, woody perennial fruit bodies of e.g. Fomes fomentarius and Phellinus spp. Dorcatoma demonstrate specialization at least to host genera with slowly changing and long-lasting fruit bodies. Spatial isolation through development in the context, in contrast with hymenophore-dwelling Ciidae, is amplified by temporal isolation, as Dorcatominae start colonizing living or dying fruit bodies. The majority of other fungivorous beetles favouring perennial fruit bodies are able to develop only in decomposing fruit bodies.

Patterns of interactions between fungi and beetles may be compared with plant-herbivore specificity. Host specificity of herbivore arthropods spans mostly within genera or genus groups, while in some guilds monophagous species prevail. Higher diversity of herbivores in tropics is mostly explained by higher diversity of plants while data on numbers of consumers per host, consumer specialization, and beta diversity demonstrate no clear latitudinal trend [Lewinsohn \& Roslin 2008]. This study also highlights the strong influence of methodology on the derived data on host-consumer interactions. Among the critical factors are sampling method (sampling on the host preferred to trapping or fogging, I used rearing), rarity and sampling effect, taxonomic bias (I treated polypores and Coleoptera separately from other wood-decaying fungi and fungivorous insects), and spatiotemporal coverage (my dataset is both geographic and seasonal summary). Several individual beetle species for various reasons demonstrated distorted trophic preferences or unexpectedly low frequencies. Ciidae are covered in detail, but trophic profiles of the commonest polyporicolous Tenebrionidae, Dacne, and Melandryidae, even though present in the diagram, are illustrated only partially. The apparent competition, i.e. species interaction through a shared enemy [Hambäck \& Björkman 2002, Morris et al. 2004, van Veen et al. 2006] also seems to exist in fungivorous communities, involving e.g. parasitoid Meteorus spp. (Braconidae, Hymenoptera; unpublished). My observations during 


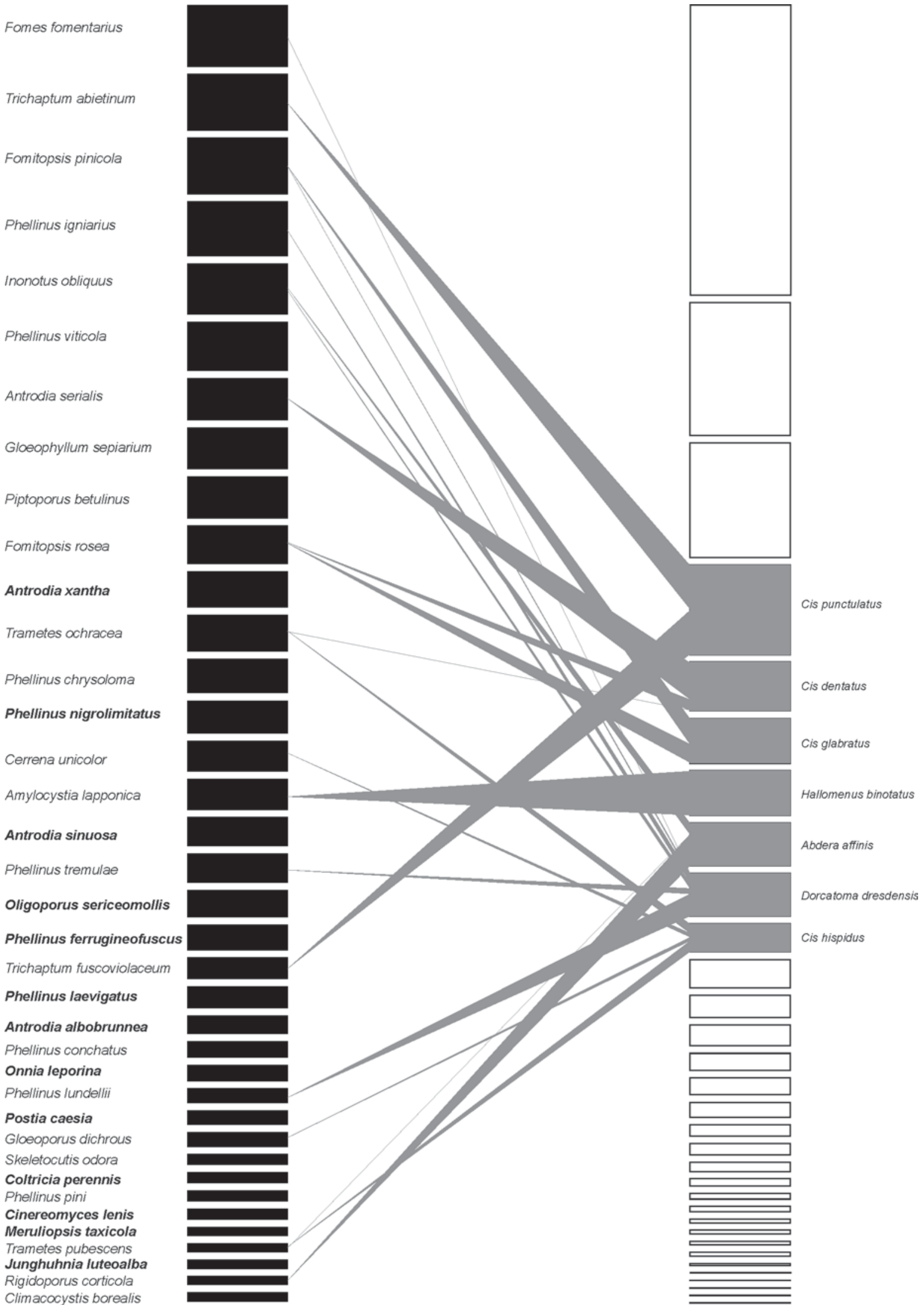

Fig. 3. Fungus-beetle food web in boreal forests: specialists. See Fig. 1 for legend.

Рис. 3. Пищевая сеть грибы-жесткокрылые в борельных лесах Финляндии: специалисты. Условные обозначения — см. Рис. 1. 
the rearing suggest that beetle-parasitoid interactions are rare in polypore fruit bodies compared with the situation among agarics and boletes. Soft and voluminous polypores, such as Polyporus squamosus (Huds.) Fr. and Grifola frondosa (Dicks.) Gray, as well as pleurotoid fungi, are likely to host more species and individuals of parasitoids, than the dry and tough polypores with perennial or annual hibernating fruit bodies.

\section{Conclusions}

The fungus-beetle food web revealed three main types of host-consumer interactions: a small group of generalist species of beetles utilized a wide range of host fungi, a few beetle species were dependent on one or two closely related host fungi, while other beetles formed species-rich communities which jointly shared a host fungus. Generalist beetles such as Ennearthron cornutum colonize structurally and seasonally similar fruit bodies, irrespectively of frequency and taxonomical similarity of the hosts. The top seven generalist beetles belonged to the family Ciidae with the exception of Dorcatoma dresdensis (Anobiidae). Ciidae also dominate among the beetles with decreasingly narrow diets. The proposed sampling scheme allowed utilizing the heterogeneous data on rare and poorly documented species, and revealing the general trends of host use in the community through the quantitative food web representation of interactions between fruit bodies of wooddecaying Basidiomycetes and larvae of Coleoptera.

ACKNOWLEDGEMENTS. Owen Lewis (University of Oxford, UK) helped with visualization of the food web diagram, using software written and supplied by Charles Godfray (NERC Centre for Population Biology, UK). Tuomo Niemelä (University of Helsinki, Finland) supervised the study and commented on the earlier version of the manuscript. Selected Dorcatoma specimens were identified by Nikolai B. Nikitsky (Moscow State University, Russia) and Ciidae by Alexander V. Kompantsev (A.N. Severtsov Institute of Ecology and Evolution, Russia). The PUTTE research programme for deficiently known and threatened forest species (Finnish Ministry of Environment), Societas pro Fauna et Flora Fennica, and Nordic Saproxylic Network are thanked for supporting the study.

\section{References}

Albrecht M., Duelli P., Schmid B., Müller C.B. 2007. Interaction diversity within quantified insect food webs in restored and adjacent intensively managed meadows // Journal of Animal Ecology. Vol.76. P.1015-1025.

Andersen J., Olberg S., Haugen L. 2000. Saproxylic beetles (Coleoptera) of Troms and western Finnmark, northern Norway, with exceptional distribution in Fennoscandia // Norwegian Journal of Entomology. Vol.47. P.29-40.

Barbosa P., Caldas A., Godfray H.C.J. 2007. Comparative food web structure of larval macrolepidoptera and their parasitoids on two riparian tree species // Ecological Research. Vol.22. P.756-766.

Crowson R.A. 1981. The Biology of Coleoptera. New York: Academic Press. 802 pp.

Ehnström B., Axelsson R. 2002. Insektsgnag i bark och ved. Uppsala: ArtDatabanken, SLU. 512 pp.
Hambäck P.A., Björkman C. 2002. Estimating the consequences of apparent competition: a method for host-parasitoid interactions // Ecology. Vol.83. P.1591-1596.

Havens K.E. 1993. Predator-prey relationships in natural community food webs // Oikos. Vol.68. P.117-124.

Hibbett D.S., Binder M., Bischoff J.F., Blackwell M., Cannon P.F., Eriksson O.E., Huhndorf S., James T., Kirk P.M., Lücking R., Lumbsch T., Lutzoni F., Matheny P.B., Mclaughlin D.J., Powell M.J., Redhead S., Schoch C.L., Spatafora J.W., Stalpers J.A., Vilgalys R., Aime M.C., Aptroot A., Bauer R., Begerow D., Benny G.L., Castlebury L.A., Crous P.W., Dai Y.-C., Gams W., Geiser D.M., Griffith G.W., Gueidan C., Hawksworth D.L., Hestmark G., Hosaka K., Humber R.A., Hyde K., Ironside J.E., Köljalg U., Kurtzman C.P., Larsson K.-H., Lichtwardt R., Longcore J., Miàdlikowska J., Miller A., Moncalvo J.-M., MozleyStandridge S., Oberwinkler F., Parmasto E., Reeb V., Rogers J.D., Roux C., Ryvarden L., Sampaio J.P., Schüßler A., Sugiyama J., Thorn R.G., Tibell L., Untereiner W.A., Walker C., Wang Z., Weir A., Weiß M., White M.M., Winka K., Yao Y.-J., Zhang N. 2007. A higher-level phylogenetic classification of the Fungi // Mycological Research. Vol.111. P.509-547.

Jonsell M., Nordlander G. 2004. Host selection patterns in insects breeding in bracket fungi // Ecological Entomology. Vol.29. P.697-705

Komonen, A. 2008: Colonization experiment of fungivorous beetles (Ciidae) in a lake-island system // Entomologisk Tidskrift. Vol.129. P.141-145.

Lawrence J.F. 1973. Host preference in Ciid beetles (Coleoptera: Ciidae) inhabiting the fruiting bodies of Basidiomycetes in North America // Bulletin of the Museum Comparative Zoology. Vol.145. P.163-212.

Lewinsohn T.M., Rolsin T. 2008. Four ways towards tropical herbivore megadiversity // Ecology Letters. Vol.11. P.398-416.

Lewis O.T., Memmott J., Lasalle J., Lyal C.H.C., Whitefoords C., Godfray C.J. 2002. Structure of a diverse tropical forest insectparasitoid community // Journal of Animal Ecology. Vol.71. P.855-873.

Martinez N.D. 1992. Constant connectance in community food webs // American Naturalist. Vol.139. P.1208-1218.

Memmott J. 1999. The structure of a plant-pollinator food web // Ecology Letters. Vol.2. P.276-280.

Memmott J., Waser N.M. 2002. Integration of alien plants into a native flower-pollinator visitation web // Proceedings of the Royal Society of London. Series B - Biological. Vol.269. P.2395-2399.

Memmott J., Godfray H.C.J., Gauld I.D. 1994. The structure of a tropical host parasitoid community // Journal of Animal Ecology. Vol.63. P.521-540.

Morris R.J., Lewis O.T., Godfray C.J. 2004. Experimental evidence for apparent competition in a tropical forest food web // Nature. Vol.428. P.310-313.

Müller C., Jaeger B., Kompantsev A.V., Uhlig M. 2001. Type and species catalogue of the minute tree-fungus beetles of the Museum für Naturkunde in Berlin, with general information on the Coleoptera collection, its curation and "Historical collection" (Coleoptera, Polyphaga, Ciidae and Pterogeniidae) // Museum für Naturkunde Berlin, Zoologische Reihe. Vol.77. P.303-323.

Müller C.B., Adriaanse I.C.T., Belshaw R., Godfray H.C.J. 1999. The structure of an aphid-parasitoid community // Journal of Animal Ecology. Vol.68. P.346-370.

Niemelä T. 2005. Käävät, puiden sienet. Polypores, lignicolous fungi // Norrlinia. Vol.13. P.1-320.

Økland B. 1995. Insect fauna compared between six polypore species in a southern Norwegian spruce forest // Fauna Norvegica. Ser.B. Vol.42. P.21-46.

Polis G.A. 1991. Complex trophic interactions in deserts: an empirical critique of food-web theory // American Naturalist. Vol.138. P.123-155.

Rassi P. (ed.) 1993. Suomen kovakuoriaisten (Coleoptera) frekvenssipisteet 1.1.1960 - 1.1.1990.// WWF Suomen Rahaston Raportteja. Vol.6. P.1-136. 
Rassi P., Hyvärinen E., Juslén A., Mannerkoski I. (eds.) 2010. The 2010 Red List of Finnish species. Helsinki: Ministry of the Environment \& Finnish Environment Institute. 685 pp.

Schigel D.S. 2007. Fleshy fungi of the genera Armillaria, Pleurotus, and Grifola as habitats of Coleoptera // Karstenia. Vol.47. P.3748

Schigel D.S. 2009. Polypore assemblages in boreal old-growth forests, and associated Coleoptera. PhD thesis // Publications in Botany from the University of Helsinki. Vol.39. P.1-44. http:/ /urn.fi/URN:ISBN:978-952-10-5825-7

Schigel D.S., Niemelä T., Kinnunen J. 2006. Polypores of western Finnish Lapland and seasonal dynamics of polypore beetles // Karstenia. Vol.46. P.37-64.

Schigel D.S., Niemelä T., Similä M., Kinnunen J., Manninen O. 2004 Polypores and associated beetles of the North Karelian Biosphere Reserve, eastern Finland // Karstenia. Vol.44. P.35-56.

Schoener T.W. 1989. Food webs from the small to the large // Ecology. Vol.70. P.1559-1589.

Thunes K.H., Midtgaard F., Gjerde I. 2000. Diversity of Coleoptera of the bracket fungus Fomitopsis pinicola in a Norwegian spruce forest // Biodiversity and Conservation. Vol.9. P.833852.
Silfverberg H. 2004. Enumeratio nova Coleopterorum Fennoscandiae, Daniae et Baltiae // Sahlbergia. Vol.9. P.1-111.

Stokland J.N., Dahlberg A., Meyke E. Schigel D.S., Siitonen J. 2006. The Nordic saproxylic database - a comprehensive overview of the biological diversity in dead wood // I European Congress of Conservation Biology, Hungary, 22-26 August 2006. P.159.

Tylianakis J.M., Tscharntke T., Lewis O.T. 2007. Habitat modification alters the structure of tropical host-parasitoid food webs // Nature. No.445. P.202-205.

van Veen F.J.F., Morris R. J., Godfray H.C.J. 2006. Apparent competition, quantitative food webs, and the structure of phytophagous insect communities // Annual Review of Entomology. Vol.51. P.187-208.

van Veen F.J.F., Müller C.B., Pell J.K., Godfray H.C.J. 2008. Food web structure of three guilds of natural enemies: predators, parasitoids and pathogens of aphids // Journal of Animal Ecology. Vol.77. P.191-200.

Worthen W.B., Carswell M.L., Kelly K.A. 1996. Nested subset structure of larval mycophagous fly assemblages: nestedness in a non-island system // Oecologia. Vol.107. P.257-264.

Worthen W.B., Jones M.T., Jetton R.M. 1998. Community structure and environmental stress: desiccation promotes nestedness in mycophagous fly communities // Oikos. Vol.81. P.45-54. 